\title{
Trace and Toxic Elements in the Soils of Different Ecosystems of Plateau Areas of the South Urals
}

\author{
Ilgiz G. Asylbaev ${ }^{*}$, Ilyusya M. Gabbasova ${ }^{2}$, Ilgiz K. Khabirov ${ }^{1}$, \\ Rustam A. Lukmanov ${ }^{1}$, Ayrat N. Khasanov ${ }^{1}$ \\ ${ }^{1}$ Federal State Budgetary Educational Establishment of Higher Education \\ "Bashkir State Agrarian University", 34 50-letiya Oktyabrya Str., 450001 Ufa, Russia \\ ${ }^{2}$ Federal State Budgetary Institution of Science, Ufa Institute of Biology, \\ Ufa, 69 Prospekt Oktyabrya, 450054 Ufa, Russia
}

Received: 21 July 2020

Accepted: 1 November 2020

\begin{abstract}
The content and distribution of toxic elements in the rocks and soils of the Belebey plateau highlands, Ufa plateau and Zilair plateau were studied. The content of elements is determined by both natural and man-made factors. Natural accumulation is mainly related to the chemical composition of parent rocks. The parent rocks in Ufa plateau and Belebeyev plateau highlands are sedimentary with a big quantity of carbonates, and for the soils of the Zilair plateau - volcanic rocks. Man-made accumulation is characterized by a regression-accumulative type of distribution, which is manifested in an increased content in the humus-accumulative horizons and a sharp decrease in the lower ones. The accumulation of elements is associated with the extraction and processing of minerals, industrial emissions from enterprises, local wind and water transport of dust particles and aerosols from ash and slag dumps, and underground waste storage facilities. The amount of toxic elements in soils can also be determined by their belonging to various ecosystems (forest, arable land, meadow). The total chemical indicator in the research areas varies from strong to weak, and environmental conditions worsen in the areas: Belebey plateau highlands - Ufa plateau - Zilair plateau.
\end{abstract}

Keywords: soils contamination, hazard class, parent rock, soil

\section{Introduction}

The study of chemical elements, including toxic ones, is the primary task of modern soil science in conditions of increasing anthropogenic impact on the environment. For various reasons, natural environments are overloaded with compounds of heavy metals,

*e-mail: ilgiz_bsau@rambler.ru and some of them constitute a very dangerous group of substances. Therefore, it is important to quantify these flows and study their potential impact on natural ecosystems $[1,2]$. Typically, 14 elements are considered: mercury, lead, cadmium, arsenic, antimony, tin, zinc, aluminum, beryllium, iron, copper, barium, chromium, thallium. Heavy metals include more than 40 metals of the periodic system of Mendeleev with an atomic mass of more than 50 atomic units: V, Cr, Mn, Fe, Co, Ni, $\mathrm{Cu}, \mathrm{Zn}, \mathrm{Mo}, \mathrm{Cd}, \mathrm{Sn}, \mathrm{Hg}, \mathrm{Pb}, \mathrm{Bi}$, etc. At the same time, 
not all of these elements are poisonous, some of them are necessary for the functioning of humans, animals, and plants [3-6].

Many chemical elements, especially microelements, have become absolutely necessary for organisms (iodine, zinc, copper, manganese, molybdenum, boron, etc.). The elements carry out various catalytic and regulatory functions of metabolic processes - absorption, transport, oxidation-reduction, biosynthesis of organic compounds, transmission of genetic information. Thus, all the organisms, even if they are fully provided with macrobiophiles (carbon, oxygen, hydrogen, nitrogen, potassium, phosphorus, calcium), cannot develop normally without the abovementioned elements. At the same time, if at abnormally high concentrations, they are inhibitory and toxic to plants, animals, and humans [7-9]. An increase in the content of elements (copper, zinc, chromium, molybdenum, manganese) is accompanied by a positive biological response, then the maximum level comes and then it drops to negative values, i.e. the biological response of the body becomes negative, and the element becomes toxic.

The founder of biogeochemistry, academician V.I. Vernadsky [10] wrote: "Living matter covers and regulates all or almost all chemical elements in the biosphere. They are all needed for life and do not enter the body by chance. There are no special life-like elements. There are "dominant." For example, scientists Bertini and Gray [11] found about 10 tungstencontaining enzymes in thermophilic microorganisms. At the same time, tungsten is an element with a large atomic number (74), although, as a rule, elements with an atomic number of not more than 35 are used in biological systems. The number of biological elements is expanding today, including arsenic, bromine, strontium, cadmium, barium, tungsten, tin. In this regard, the content of the element, the form of its compounds and the relationship with other elements are of decisive importance.

Plants also have the ability to inactivate excess amounts of heavy metals in tissues, which is determined largely by their species characteristics [12-14]. For each element, four levels of concentrations have to be distinguished, in addition to the form of the compounds and the relationship with the others: "element deficiency", when the body suffers from a deficiency, "optimal content", which contributes to a good state of the body, "permissive concentrations", when the body's depression is only beginning to appear, and "fatal concentrations" for a given organism. In recent years, the main attention of agrochemists, agroecologists and soil scientists has been focused on studying the issues of soil, natural waters and plants pollution, caused by emissions from industrial enterprises. Currently, standards for the content of a number of substances have not been established, and the level of toxicity of elements largely depends on the genetic properties of the soil (content of humus, nutrients and secondary minerals, $\mathrm{pH}$ of the medium, redox conditions, etc.), the stability of natural plants and crops. Many scientists [15-17] consider it more appropriate to orientate on background values. The concentrations of substances exceeding their natural content by 5,10 or more times are considered toxic. The main disadvantage of the environmental assessment by MAC (maximum allowable concentration) is the fact that the addition of the negative effects of several elements, each of which is present in subcritical concentrations, is not considered [18, 19]. Obviously, if the content of many elements is increased, then their combined effect can lead to environmental disaster.

It is important to know the toxicants content in soils and the environment for several reasons. First, it will allow soil scientists to predict the behavior of pollutants in the soil, depending on its particle size distribution and mineralogical composition, degree of humus content, acid-base and redox conditions, and other properties. Secondly, it will help to solve the problems of remediation of contaminated soils. Thirdly, the correct design of artificial geochemical barriers allows the successful purification of contaminated soil and groundwater before it enters rivers or lakes. This requires knowledge of the reactivity of the reagents when fixing one or another pollutant to the barrier [20].

In the Republic of Bashkortostan, the content of alkaline, alkaline-soil, rare-soil, and radioactive elements in the soils of meadow, forest, and agroecosystems has been fairly well studied. The studies conducted in the soils of the Republic showed the presence of anthropogenic and natural accumulation of chemical elements in soils [21-24]. In the Republic, there are different conditions for the formation of the Earth crust, its mosaic, altitudinal and latitudinal zonality and the related features of climate, soil and vegetation. In this regard, a significant role in the accumulation and migration of elements belongs to the plateau-like highlands of the Southern Urals.

The aim of the work is a geochemical assessment of the elemental composition of soils on plateau-like highlands of the Southern Urals.

The research tasks included determining the content of toxic elements in the soils of plateau-like highlands of the Southern Urals, identifying differences in their accumulation and distribution in the profile depending on the geographical location.

The objects of research were the soils formed on plateau-like hills: the Ufa plateau $(300-520 \mathrm{~m})$, Belebey plateau highland (200-450 m), Zilair plateau (300-600 m).

\section{Material and Methods}

The studies were conducted from 1999 to 2018 on permanent stationary sites in forest, meadow and agroecosystems. A total of 22 full-profile soil sections were laid, including on the Ufa plateau -7 sections in 4 stationary sections (Bayki, Maginsk, Abyzovo, 


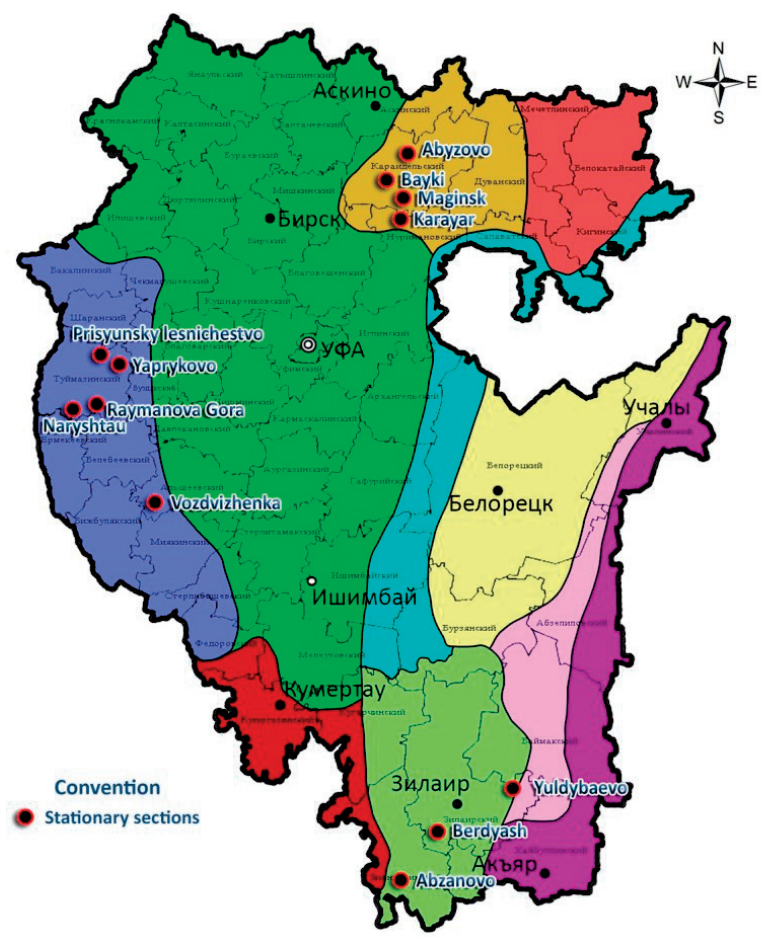

Fig. 1. Stationary sections.

Karayar), Belebey plateau highland -8 sections in 5 stationary sections (Raymanova Gora, Prisyunsky lesnichestvo, Yaprykovo, Vozdvizhenka, Naryshtau), Zilair plateau - 7 sections in 3 stationary sites (Abzanovo, Berdyash, Yuldybaevo) (Fig. 1).

The content of the gross forms of elements in rocks and soils was determined by inductively coupled plasma mass spectrometry - IPC-MS on a VG Plasma Quad and Elan-6100 mass spectrometer ("Perkin-Elmer", USA) under standard conditions of change using imported reference samples in a certified laboratory of the Federal State Unitary Enterprise "All-Russian Scientific Research Institute of Mineral Resources named after N.M. Fedorovsky". To calibrate the instrument, standard solutions containing a set of appropriate elements are used. The error in determining elements at the level of units and hundredths is not more than $15 \%$. The determination of the concentration of elements is based on the following: the analyzed solution is atomized and, with an argon flow, enters a high-temperature plasma, where most atoms are ionized. Part of the ions formed in the plasma enters the vacuum chamber, in which they are accelerated and focused using ion lenses. Next, the ion beam enters the inhomogeneous electromagnetic field of the quadrupole, where the spatial separation of ions by mass occurs. When scanning the electromagnetic field of a quadrupole, ions of a certain mass sequentially fall onto the ion detector and are recorded using electrical measuring devices. The received signals, proportional to the content of certain ions in the plasma, are processed using a computer system, and the analysis results are printed by the printer. The preparation and selection of soil samples was carried out in accordance with certified methods [25]. The samples were taken along the main genetic horizons of the soil profile after laying the soil section, including the humus-accumulative horizon (A), illuvial (B) and parent soil (C). When selecting soil samples, the patterns of soil cover formation in landscapes were taken into account. Genetic horizons were visually isolated, soil samples weighing $300 \mathrm{~g}$ were taken and their laboratory analysis was carried out after drying and sieving through sieves with a diameter of $0.25 \mathrm{~mm}$.

The geochemical assessment of soils according to the content of elements and the degree of contamination was carried out in accordance with the scales developed by Asylbaev, Khabirov [26, 27] for the conditions of the Republic of Bashkortostan (hereinafter referred to as the "scale"). When compiling the scales, the background contents characteristic of these territories were used. In the present work, the average data on the minimum amounts of elements in the soils of the region were taken as the background content. The indicators of the corresponding elements were compared with them in order to detect high, medium low and very low (background) contents (Table 1).

The total chemical indicator was calculated as the sum of the concentration coefficients of substances according to the Saeta formula [28]. The evaluation technique is as follows, the role of individual elements within their toxicity class was determined in relation to the background indicators and expressed as a percentage. The total chemical index was calculated as the sum of the concentration coefficients of substances according to the formula: $Z c=\sum_{i=1}^{n} \mathrm{KCi}-(n-1)$, where $\mathrm{n}$ is the number of elements analyzed; $\mathrm{KCi}$ is the concentration coefficient of the $\mathrm{i}$-th element, $\mathrm{KCi}$ $=\mathrm{Ci} / \mathrm{Cfi}, \mathrm{Ci}-$ the actual content of the element, Cfi background content [28]. The background values were determined by the minimum value or the average of several minimum values for each research area. The obtained calculations of $\mathrm{Zc}$ were compared with the available categories of total soil pollution according to Table 2.

\section{Results and Discussion}

The Ufa Plateau is a flat highlands with a strongly dissected karst-erosion relief composed of hard limestones, dolomites, variegated marls, and in places sandy deposits. The parent rocks are mainly represented by limestone eluvial-deluvial clays. On the Ufa Plateau, the soils of stationary sites are represented by gray forest (Greyic Phaeozems Albic), peaty humus residualcarbonate soils (Histic Cryosols Reductaquic). The humus-carbonate soils are more confined to mossy fir forests, pine forests and spruce forests. In these soils, under the poorly decomposed peaty litter, an organicmineral horizon lies, consisting of humus and small fragments of crushed stone of carbonate rocks, the fine earth is often leached from carbonates, and boiling of 
Table 1. Scales for assessing the level of soil pollution by elements, $\mathrm{mg} / \mathrm{kg}[26,27]$.

\begin{tabular}{|c|c|c|c|c|c|}
\hline \multirow{2}{*}{ Elements } & \multicolumn{5}{|c|}{ Levels of availability (pollution) of soil elements } \\
\cline { 2 - 6 } & Permissible & Weak & Average & Strong & Very strong \\
\hline $\mathrm{Zn}$ & $<50$ & $51-100$ & $101-150$ & $151-200$ & $>200$ \\
\hline $\mathrm{As}$ & $<10.0$ & $10.1-20.0$ & $20.1-30.0$ & $30.1-40.0$ & $>40$ \\
\hline $\mathrm{Pb}$ & $<10$ & $10.1-15$ & $15.1-20$ & $20.1-25$ & $>25$ \\
\hline $\mathrm{Cu}$ & $<10$ & $11-30$ & $31-50$ & $51-70$ & $>70$ \\
\hline $\mathrm{Mo}$ & $<0.5$ & $0.51-1.0$ & $1.1-1.50$ & $1.51-2.0$ & $>2.0$ \\
\hline $\mathrm{Co}$ & $<5$ & $5.1-10$ & $10.1-20$ & $20.1-30$ & $>30$ \\
\hline $\mathrm{Ni}$ & $<50$ & $51-100$ & $101-150$ & $151-200$ & $>200$ \\
\hline $\mathrm{Cr}$ & $<50$ & $51-100$ & $101-150$ & $151-200$ & $>2.5$ \\
\hline $\mathrm{W}$ & $<1.0$ & $1.01-1.5$ & $1.51-2.0$ & $2.01-2.5$ & $>400$ \\
\hline $\mathrm{V}$ & $<100$ & $101-200$ & $201-300$ & $301-400$ & $>200$ \\
\hline $\mathrm{Sr}$ & $<50$ & $51-100$ & $101-150$ & $151-200$ & $>1500$ \\
\hline $\mathrm{Ba}$ & $<100$ & $101-500$ & $501-1000$ & $1001-1500$ & $>12$ \\
\hline $\mathrm{Th}$ & $<4$ & - & $4-8$ & $8-12$ & $10-15$ \\
\hline $\mathrm{U}$ & $<5$ & - & $5-10$ & & $>15$ \\
\hline
\end{tabular}

$10 \%$ hydrochloric acid is rapid only over fragments of crushed stone. The most common feature of soils formed on the Ufa plateau is the shortening of the soil profile, and the presence of carbonates in its lower part. In the process of soil development, with a decrease in the influence of the carbonate content of parent rocks, a podzolic process begins to appear in them. A feature of the region's soils is also a relatively high humus content, which is due to the mineralization of a sufficiently large forest litter and plant debris in the continental climate and the close occurrence of calcareous bedrock, the composition and properties of which contribute to the neutralization of acid decomposition products and the fixation of humus in the form of calcium humates. These soils are saturated with bases, the reaction of the medium varies from slightly acidic to slightly alkaline.

On the Belebey plateau-like highlands, mainly black soils (Voronic Chernozems Pachic), and to

Table 2. Categories of total soil pollution following [28].

\begin{tabular}{|c|c|}
\hline Category of soil pollution & $\mathrm{Z}_{\mathrm{c}}$ \\
\hline Permissible & $1-8$ \\
\hline Weak & $8-16$ \\
\hline Average & $16-32$ \\
\hline Strong & $32-64$ \\
\hline Very strong & $64-128$ \\
\hline
\end{tabular}

$\mathrm{Zc}-$ is the sum of the toxicants concentration coefficients in relation to the background indicators, calculated using the Saeta formula a lesser extent gray (Greyic Phaeozems Albic) and darkgray forest soils (Greyic Phaeozems Albic) are formed. The parent rocks are mainly deluvial carbonate clays, heavy and light loams and limestone eluvium. The chernozems are typical, for the most part, of medium power. Morphological features are the intense dark gray color of the humus horizon, good lumpy-granular structure, loose constitution, and an increased level of boiling from $\mathrm{HCl}$. The humus content varies over a wide range from 4.7 to $12.8 \%$, virgin soils are usually high humus, and arable soils are medium humus. Granulometric composition is heavy loamy, sometimes medium loamy. The reaction of the medium is close to neutral or slightly alkaline in the presence of free carbonates. The soils are saturated with bases, in which calcium predominates. These properties determine the high absorption capacity and buffering of typical chernozems, i.e. high environmental sustainability. Gray and dark gray forest soils are characterized by a lesser thickness of humus-accumulative horizon, gray and dark gray color, lumpy-fine-grained structure, and the presence of a pronounced densified illuvial horizon. The humus content in gray forest soil is $4.1 \%$, and in dark gray $-7.9 \%$, with depth, the humus content of both soils decreases sharply. The upper horizons are characterized by a slightly acid reaction of the medium, which becomes neutral towards the bottom of the profile. The formation of these soils on the eluvium of carbonate rocks led to a significant content of absorbed bases in the soil-absorbing complex.

On the Zilair Plateau, the soil cover is represented by dark gray forest (Greyic Phaeozems Albic), mountain dark gray forest (Leptosols Eutric) and meadow 
chernozem soils (Voronic Chernozems Pachic). These soils were formed on bedrock: dolomites, shales and sandstones. The thickness of the humus horizons of dark gray and gray forest soils $\mathrm{A}+\mathrm{AB}$ is $38-54 \mathrm{~cm}$, they are characterized by small reserves of humus, a low amount of absorbed bases and acidic reaction of the medium. Meadow-chernozem soils are characterized by a greater thickness of the humus horizon and a high content of exchange bases. In the humus horizon, the sum of the absorbed bases is $57-65 \mathrm{mEq}$ per $100 \mathrm{~g}$ of soil, illuvial - about $47 \mathrm{mEq}$ in parent rock - 40-54 mEq. The composition of the absorbed bases contains more than 2-3 times more calcium than magnesium. The humus content is average, the $\mathrm{pH}$ of the salt extract varies with depth from slightly acidic to slightly alkaline. Mountain dark gray forest soils are characterized by a lower thickness of the humus horizon, chastity, close to a neutral reaction of the environment. By granulometric
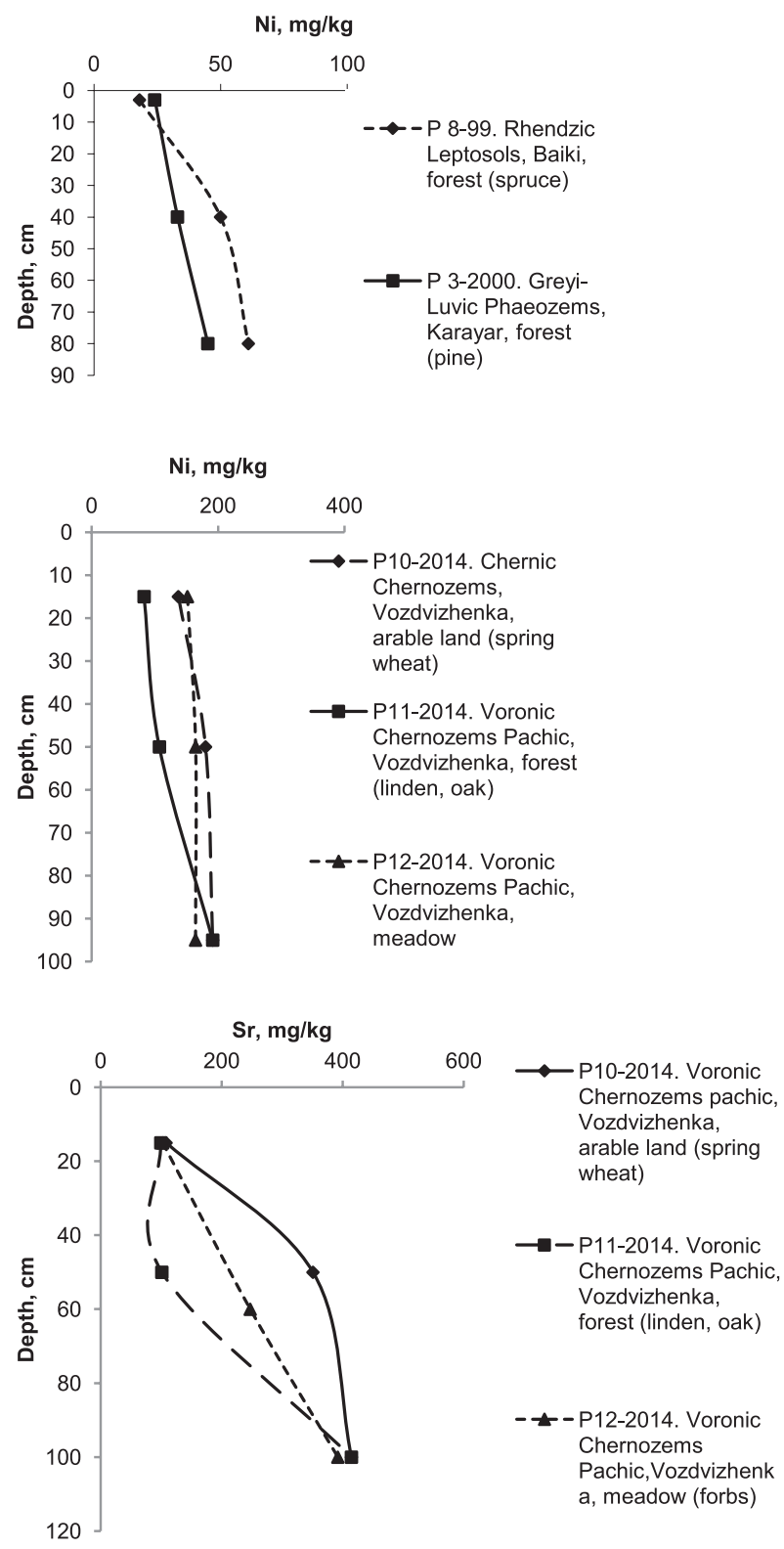

Fig. 2. Distribution of nickel along the soil profile. composition they are heavy loamy. These soils are characterized by a relatively high humus content in the humus-accumulative horizon and a sharp decrease in its profile.

The geographical position, geomorphological and geological structure of the hills determined the differences in the accumulation of toxic elements in soils. The content of elements varies over a wide range from 0.1 to $103 \mathrm{mg} / \mathrm{kg}$ (Table 1). The accumulation of elements in soils is anthropogenic and natural. Nickel, strontium, chromium and uranium penetrate into the soils of plateau-like hills from parent rocks and in the soil profile their characteristics is similar (Fig. 2).

With a high content in parent and bedrocks, these elements on the one hand are carried away by trees, on the other hand, when toxicants with dusty air masses arrive, they settle on the leaves and crowns of trees and, after washing off with rainfall and leaf fall, enter the
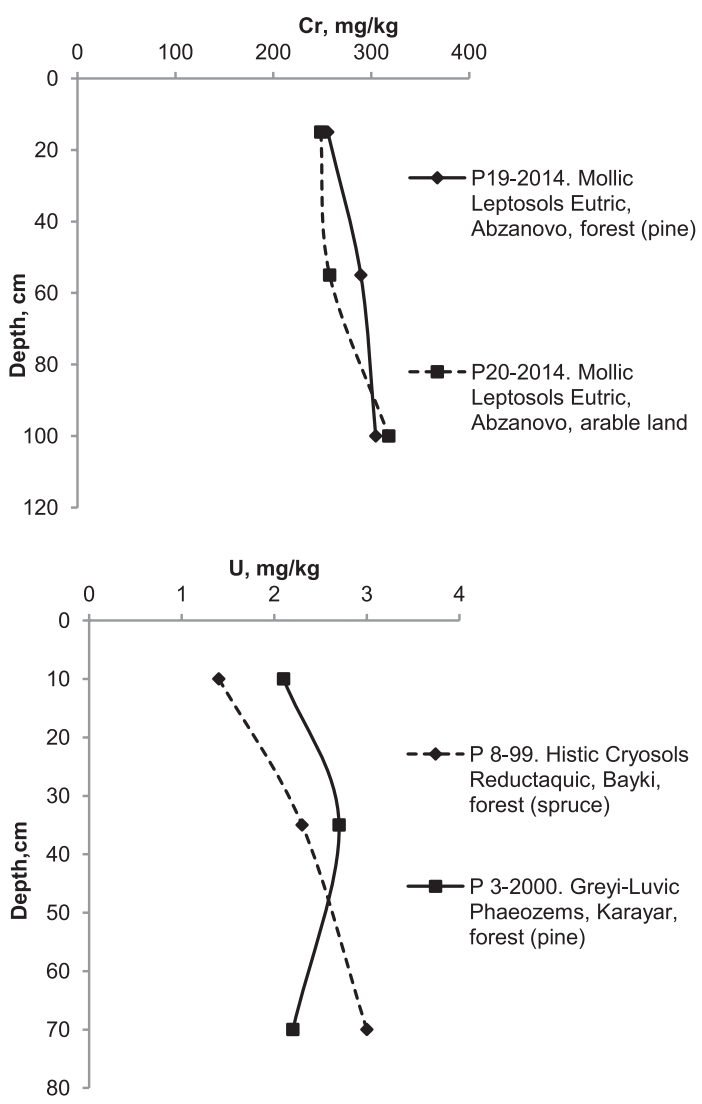
Table 3. Correlation dependence of the content of toxic elements in horizons A and $\mathrm{AB}$ on their concentration in the rock.

\begin{tabular}{|c|c|c|c|c|c|c|}
\hline \multirow{2}{*}{ Element } & \multicolumn{3}{|c|}{$\mathrm{y}\left(\mathrm{A}_{0}\right)$ from $\mathrm{C}(\mathrm{X})$} & \multicolumn{3}{|c|}{$\mathrm{y}(\mathrm{AB})$ from $\mathrm{X}(\mathrm{C})$} \\
\cline { 2 - 7 } & $\mathrm{r}$ & $\mathrm{t}_{\mathrm{st}}$ & Equation & $\mathrm{r}$ & $\mathrm{t}_{\mathrm{st}}$ & Equation \\
\hline Chromium & 0.97 & 8.0 & $\mathrm{y}=32.2+0.51 \mathrm{x}$ & 0.83 & 7.69 & $\mathrm{y}=1.67+0.84 \mathrm{x}$ \\
\hline Nickel & 0.96 & 6.92 & $\mathrm{y}=28.5+0.42 \mathrm{x}$ & 0.99 & 11.9 & $\mathrm{y}=15.2+0.56 \mathrm{x}$ \\
\hline Molybdenum & 0.77 & 2.41 & $\mathrm{y}=0.62+0.16 \mathrm{x}$ & 0.83 & 2.96 & $\mathrm{y}=0.55+0.27 \mathrm{x}$ \\
\hline Strontium & 0.88 & 3.68 & $\mathrm{y}=28.2+0.52 \mathrm{x}$ & 0.87 & 35.3 & $\mathrm{y}==0.09+0.82 \mathrm{x}$ \\
\hline Copper & 0.88 & 3.74 & $\mathrm{y}=0.88 \mathrm{x}-2.88$ & 0.83 & 2.99 & $\mathrm{y}=5.11+0.67 \mathrm{x}$ \\
\hline Barium & 0.91 & 4.47 & $\mathrm{y}=305+29 \mathrm{x}$ & 0.96 & 7.01 & $\mathrm{y}=245+0.35 \mathrm{x}$ \\
\hline Vanadium & 0.91 & 4.3 & $\mathrm{y}=16.1+0.66 \mathrm{x}$ & 0.99 & 12.62 & $\mathrm{y}=27.6+0.65 \mathrm{x}$ \\
\hline Tungsten & 0.69 & 1.89 & $\mathrm{y}=0.43+0.32 \mathrm{x}$ & 0.95 & 6.39 & $\mathrm{y}=0.27+0.45 \mathrm{x}$ \\
\hline
\end{tabular}

$\mathrm{r}-$ is the correlation coefficient at $95 \%$ probability, $\mathrm{t}_{\mathrm{st}}-$ Student's criterion $(2.45)$

upper layers of the soil, and due to partial assimilation by trees they move into the root system and accumulate in the lower horizons of the soil.

The most common is the high content of copper, nickel, strontium and uranium in soils formed on sedimentary calcareous rocks of the Belebey Plateau Highlands and the Zilair Plateau, while in the Ufa Plateau this content is low. The soils of the Zilair plateau are characterized by a higher content of cobalt, chromium and tungsten, the Ufa plateau - arsenic, lead and thorium. This difference is explained by the fact that the soils of the Ufa plateau were formed on sedimentary rocks containing a large number of carbonates, and for the soils of the Zilair plateau volcanic carbonate-free rocks were parent rocks (Table 1).

The positive relationship was found between the content of toxic elements in the soil and in the rocks of the republic (Table 3). The functional dependence with the content of humus was not reliable. At the same time, theoretically, the strong positive anomalies of uranium detected in peat bogs are examples of the effective operation of natural organogenic geochemical barriers in the humid zone [29]. The influence of organic matter is especially significant: humic acids are able to form complexes with U (VI), facilitating the leaching of uranium from the parent rock, the fractions of organic matter available to microorganisms serve as a source of energy necessary for the recovery of $U$, humic acids also serve as an electronic shuttle for bacterial reduction of U. Biota due to enzymes acts as a catalyst for the recovery process $\mathrm{U}[30,31]$.

A direct reliable dependence of the $\mathrm{V}$ content on silty particles was noted in the chernozems of the Central Chernozem region [32]. On the coast of Vigo in northwestern Spain, the V content in sediments correlates with the amount of silt fraction [33].

The content of zinc, molybdenum, vanadium and barium in soils of all plateau-like highlands is estimated mainly as medium and low.
The content of other elements in parent rocks is lower than in soils, which is determined mainly by anthropogenic factors; they are characterized by a regression-accumulative type of distribution, which is manifested in increased accumulation in humusaccumulative horizons and a sharp decrease in the content in the lower ones. The accumulation of elements is associated with the extraction and processing of minerals, industrial emissions from industrial enterprises, local wind and water transport of dust particles and aerosols from ash and slag dumps, and underground waste storage facilities.

Particular attention is paid to the Yuldybaevo stationary in the Zilair plateau, where the lead content in soils varies in horizons $\mathrm{A}$ and $\mathrm{C}$ depending on the ecosystem (Fig. 2). In humus-accumulative horizons, the highest amount of lead was recorded in the old plowed area, less in the meadow, and the lowest under the forest. In the illuvial horizons of all soils, it is almost the same, but in the parent rock there is a sharp discrepancy - an increase under arable land and a decrease under a forest and meadow. In soils, $\mathrm{Pb}$ exhibits an affinity for various components. Among

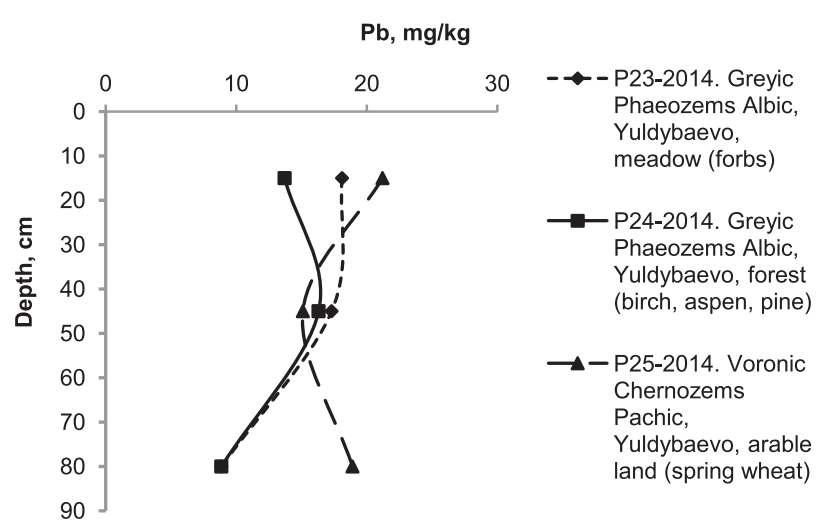

Fig. 3. Distribution of lead over the soil profile of the Zilair plateau. 
Table 4. The content of chemical elements in soils and parent rocks, $\mathrm{mg} / \mathrm{kg}$.

\begin{tabular}{|c|c|c|c|c|c|c|c|c|c|c|}
\hline \multirow{3}{*}{ Elements } & \multirow{3}{*}{$\begin{array}{l}\text { Content } \\
\text { limits }\end{array}$} & \multicolumn{9}{|c|}{ The content of elements by research area, $\mathrm{mg} / \mathrm{kg}$} \\
\hline & & \multicolumn{3}{|c|}{ Belebey plateau-like highlands, $\mathrm{n}=8^{*}$} & \multicolumn{3}{|c|}{ Ufa plateau, $\mathrm{n}=7^{*}$} & \multicolumn{3}{|c|}{ Zilair plateau, $\mathrm{n}=7^{*}$} \\
\hline & & Rocks & Soils & $\begin{array}{c}\text { Level of } \\
\text { contamination }\end{array}$ & Rocks & Soils & $\begin{array}{c}\text { Level of } \\
\text { contamination }\end{array}$ & Rocks & Soils & $\begin{array}{c}\text { Level of } \\
\text { contamination }\end{array}$ \\
\hline \multirow{2}{*}{$\mathrm{Zn}$} & $\max * *$ & 59.8 & 78.6 & \multirow{2}{*}{ Weak } & 94 & 61.5 & \multirow{2}{*}{ Weak } & 118.5 & 101.2 & \multirow{2}{*}{ Average } \\
\hline & $\min * *$ & 3.5 & 2.3 & & 29 & 26.7 & & 30.3 & 49.7 & \\
\hline \multirow{2}{*}{ As } & $\max * *$ & 8.2 & 8.8 & \multirow{2}{*}{ Permissible } & 40 & 31.5 & \multirow{2}{*}{ Strong } & 11.8 & 9.7 & \multirow{2}{*}{ Permissible } \\
\hline & $\min * *$ & 2.1 & 1.3 & & 19 & 17.3 & & 1.5 & 4.6 & \\
\hline \multirow{2}{*}{$\mathrm{Pb}$} & $\max * *$ & 10.6 & 15.9 & \multirow{2}{*}{ Average } & 26 & 32 & \multirow{2}{*}{ Very strong } & 18.9 & 18.2 & \multirow{2}{*}{ Average } \\
\hline & $\min * *$ & 5.1 & 6.5 & & 1.4 & 1.1 & & 4.5 & 7.7 & \\
\hline \multirow{2}{*}{$\mathrm{Cu}$} & $\max * *$ & 32 & 63.6 & \multirow{2}{*}{ Strong } & 30 & 15.5 & \multirow{2}{*}{ Weak } & 92.5 & 80.4 & \multirow{2}{*}{ Very strong } \\
\hline & $\min * *$ & 15.3 & 19.9 & & 0.1 & 1.6 & & 24.3 & 39.4 & \\
\hline \multirow{2}{*}{ Mo } & $\max * *$ & 0.51 & 0.7 & \multirow{2}{*}{ Weak } & 1 & 0.7 & \multirow{2}{*}{ Weak } & 2.4 & 1.1 & \multirow{2}{*}{ Average } \\
\hline & $\min * *$ & 0.1 & 0.1 & & 0.1 & 0.3 & & 0.3 & 0.5 & \\
\hline \multirow{2}{*}{$\mathrm{Co}$} & $\max * *$ & 17.9 & 19.3 & \multirow{2}{*}{ Average } & 13 & 12 & 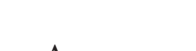 & 35.1 & 27 & \\
\hline & $\min * *$ & 6.6 & 6.5 & & 7.4 & 4.9 & Rverage & 4.1 & 8.3 & Nirong \\
\hline & $\max ^{* *}$ & 191.5 & 169.6 & & 64 & 43 & & 450 & 408.8 & \\
\hline $\mathrm{NI}$ & $\min * *$ & 37.1 & 38.5 & Strong & 36 & 28.5 & remintasioie & 45 & 58 & very strong \\
\hline & $\max * *$ & 132.8 & 126.8 & & 76 & 71.5 & & 317.9 & 283.2 & \\
\hline$U_{1}$ & $\min * *$ & 23.2 & 27.2 & Average & 34 & 33 & weak & 129 & 118 & very strong \\
\hline & $\max * *$ & 1.26 & 1.7 & & 1.0 & 1.0 & & 3.2 & 2.4 & \\
\hline $\mathrm{w}$ & $\min * *$ & 0.1 & 0.1 & Average & 0.7 & 0.6 & remimastoie & 0.7 & 0.9 & Strong \\
\hline & $\max * *$ & 68 & 103.2 & & 200 & 152 & & 162.4 & 133.8 & \\
\hline$v$ & $\min * *$ & 31.7 & 55.1 & weak & 34 & 39.5 & weak & 72.6 & 86 & weak \\
\hline & $\max * *$ & 415 & 187.3 & & 120 & 88 & & 336.6 & 247.3 & \\
\hline SI & $\min * *$ & 100.8 & 80.1 & Strong & 82 & 64.3 & weak & 59.2 & 65.3 & very strong \\
\hline & $\max * *$ & 634 & 630 & & 206 & 218.5 & & 413 & 412.7 & \\
\hline $\mathrm{Ba}$ & $\min * *$ & 29.5 & 195.8 & Average & 139 & 132.3 & Weak & 63.6 & 95.4 & weak \\
\hline & $\max * *$ & 2.0 & 6.1 & & 16 & 13.5 & & 0.3 & 2.4 & \\
\hline In & $\min * *$ & 0.3 & 1.9 & Average & 9.3 & 7.8 & very strong & 0.1 & 1.2 & Permissible \\
\hline & $\max ^{* *}$ & 18.0 & 16.8 & & 3.0 & 2.7 & & 19.2 & 16.2 & \\
\hline 0 & $\min * *$ & 2.0 & 2.3 & strong & 1.6 & 1.5 & renImsidie & 8.0 & 10.3 & very strong \\
\hline
\end{tabular}

$* \mathrm{n}-$ is the number of sections, $* * \max$ and $\min -$ are the highest and lowest average element content for the soil profile.

them are clay minerals, especially in small humus soils and sediments. Lead is concentrated in soils and sediments of heavy particle size distribution [34, 35]. The profile distribution of the lead content indicates its surface intake and in natural ecosystems the direction of movement is characteristic of the type of gray forest soils, and on the arable land the process of lead leaching in the illuvial horizon and accumulation in the parent rock are pronounced. A similar accumulation of cobalt and molybdenum in the upper horizons and a decrease in the lower horizons is characteristic of the arable land of the Zilair plateau and the Belebey plateau highlands. Typically, in soils involved in agricultural production, the gross lead content reaches $20 \mathrm{mg} / \mathrm{kg}$ of soil at a maximum permissible concentration of $100 \mathrm{mg} / \mathrm{kg}$. It is established that liming of the soil and an increase in the response of the medium significantly reduce the lead content in plants. Lead in carbonate soils weakly enters plants, despite its increased content in soil solution [36]. Such a dependence of the intake 


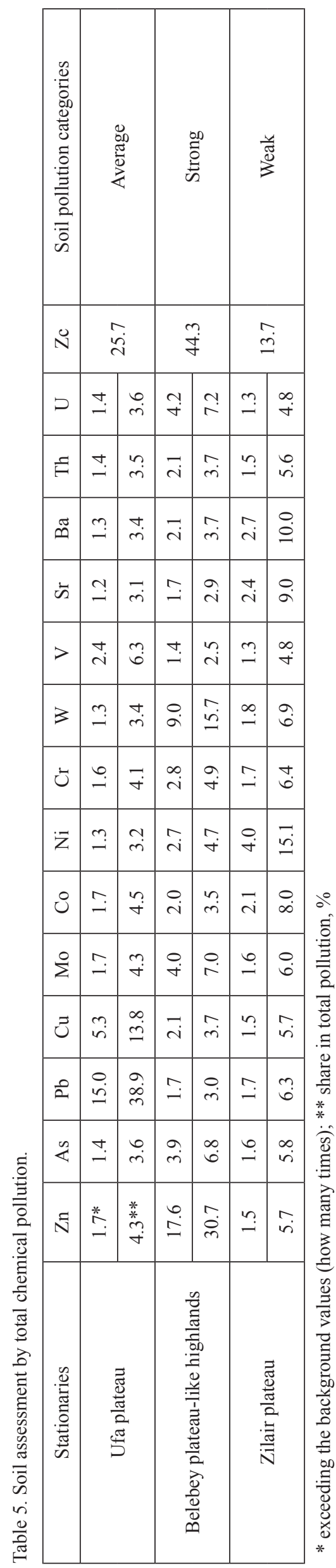

of lead into plants on the carbonate content in the soil and the $\mathrm{pH}$ value follows, first of all, from a decrease in the thermodynamic activity of free lead ions, that is, ions that are not associated with other ions. In alkaline soil solutions of carbonate alkaline soils, the molar fraction of the active concentration (activity) of lead ions does not exceed $0.13 \%$, in aqueous extracts $0.24 \%$. Whereas in cadmium, the molar fraction of the active ion concentration is much higher and amounts to 4.0 and $11.2 \%$, respectively [37] (Fig. 3).

The Saeta formula allowed to evaluate the degree of total soil contamination with toxic elements. The data obtained by us make it possible to assess the ecological situation of the geomorphological regions of the Republic of Bashkortostan by the degree of total soil pollution with toxic elements. According to the content of elements and their total chemical index, the regions vary significantly. The total chemical indicator in the research areas varies from strong to weak, and environmental conditions worsen in the following areas: Belebey Plateau Highlands - Ufa Plateau - Zilair Plateau (Table 4 and 5).

In the Ufa Plateau, the largest proportion among the elements is lead (38.9\%), where the excess of the background is 15 times $(\max -32 \mathrm{mg} / \mathrm{kg}$ ). The average lead content in the soils of the world varies from 3 to $180 \mathrm{mg} / \mathrm{kg}$, in China - from 17 to $280 \mathrm{mg} /$ $\mathrm{kg}$ [38]. The natural content of lead in soils is inherited from parent rocks, however, due to largescale aerogenic pollution in the upper layers of the soil, it can accumulate due to this. In acidic igneous rocks and clay sediments, lead is in the range of $10-40 \mathrm{mg} / \mathrm{kg}$, and in ultrabasic and calcareous rocks, $0.1-1.0 \mathrm{mg} / \mathrm{kg}$. In the Ufa Plateau, the content in carbonate rocks was $26 \mathrm{mg} / \mathrm{kg}$. During anthropogenic pollution, the highest element concentration is usually found in the humus-accumulative layer of soil [39]. According to the data of G.D. Chimitdorzhiev et al. [40], in the meadow chernozem permafrost soils and in the parent rock, the lead content averaged $12.5 \mathrm{mg} / \mathrm{kg}$, increasing in the upper horizon to $22.0 \mathrm{mg} / \mathrm{kg}$, which is much more than its clarke $(13 \mathrm{mg} / \mathrm{kg})$.

In the Belebey plateau-like highlands, the main load falls on zinc, exceeding the background level by 18 times, with a specific gravity of $30.7 \%$, and tungsten by 9 times, which is $15.7 \%$, although their content refers to a low level of pollution (78.6 and $1.7 \mathrm{mg} / \mathrm{kg}$, respectively). The average zinc content in the soils of the world is $90 \mathrm{mg} / \mathrm{kg}$ [41, 42].

In technologically contaminated podzolic soils of the Kola Peninsula, in the upper horizons, on average, $46 \mathrm{mg} / \mathrm{kg}$ of zinc with fluctuations from 12 to $198 \mathrm{mg} / \mathrm{kg}$ is contained, and in the C-horizons from 3.7 to 348 , on average, $20.9 \mathrm{mg} / \mathrm{kg}$ [43].

In the Zilair Plateau, the main pollutant is nickel, which accounts for $15.1 \%$ of the total amount and a 4-fold excess of the background value. For other elements, the excess of background values is from 1.2 to 2 units. The nickel content in the rocks of the Zilair 
Plateau is $450 \mathrm{mg} / \mathrm{kg}$, in the soil $408.8 \mathrm{mg} / \mathrm{kg}$, which is also much higher than the MAC standard $(85 \mathrm{mg} / \mathrm{kg})$ [44]. On average, the soils of the Republic of Belarus contain $20.0 \mathrm{mg} / \mathrm{kg} \mathrm{Ni}$, the average $\mathrm{Ni}$ content in peat soil is $4 \mathrm{mg} / \mathrm{kg}$ [45]. The analysis of data on the $\mathrm{Ni}$ content in sod-podzolic soils showed that its content in all soil samples is significantly lower than the regional clarke [46].

The highest concentrations of nickel, as a rule, are observed in clayey and loamy soils, in soils formed on the main and volcanic rocks and rich in organic matter. The distribution of $\mathrm{Ni}$ in the soil profile is determined by the content of organic matter, amorphous oxides and the amount of clay fraction. On the coast of Vigo Island in northwestern Spain, the average nickel content in clay sediments is three times higher than in sandy ones [47]. A direct reliable dependence of the nickel content on the amount of silty particles was noted in the gray forest soils of the Central Black Earth Region [48]. Nickel also manifests itself as a siderophile. On the coast of Vigo Island in Spain, the amount of $\mathrm{Ni}$ in the sediments reliably correlates with the total iron content: $\mathrm{r}=0.63$, which indicates the affinity of nickel with iron (hydr)oxides [35].

\section{Conclusions}

The geographical position and geomorphological structure of the highlands have a number of common features and differences that determine the nature of the accumulation of elements. The most common is the increased content of elements in the soils and rocks of these elevations and is determined by both natural and man-made factors. The natural accumulation of cobalt, strontium, vanadium, tungsten, arsenic and nickel is mainly due to soil-forming processes and their content in soil-forming, acidic and basic rocks.

The accumulation of lead, zinc, copper, chromium, molybdenum and barium is determined mainly by manmade factors; they are characterized by a regressionaccumulative type of distribution, which manifests itself in increased accumulation in humus-accumulative horizons and a sharp decrease in the content in the lower ones. The accumulation of elements is associated with the extraction and processing of minerals, industrial emissions from industrial enterprises, local wind and water transport of dust particles and aerosols from ash and slag dumps, and underground waste storage facilities.

Among the elements in all soils, the main pollutants are copper, nickel, strontium and uranium, and an acceptable level of content is characteristic of molybdenum, zinc and vanadium. Under conditions of predominantly natural pollution factors, strong and very strong categories were identified in the Zilair plateau and are caused by the accumulation of copper, cobalt, nickel, chromium, tungsten, strontium and uranium; Belebey plateau-like highlands - copper, nickel, strontium and uranium; Ufa plateau - arsenic, lead and thorium.

The amount of toxic elements in soils is largely determined by their belonging to various ecosystems. In the soils under the forest, the accumulation of many elements, especially strontium, tungsten, copper, chromium, cobalt, nickel, molybdenum, occurs in different ways. In arable land soils, high concentrations of cobalt and molybdenum are mainly due to their introduction with fertilizers, ameliorants and pesticides. The obtained data can become the basis for long-term and retrospective monitoring of the geochemical state of soils. According to the results of the study, environmental soil passports for individual geomorphological regions can be developed, which is also advisable to take into account when determining their market value. According to the environmental assessment and taking into account the reserves of chemical elements, areas and soils have been established which have the purity level allowing to produce environmentally friendly agricultural products.

\section{Conflict of Interest}

The authors declare no conflict of interest.

\section{References}

1. GULAN L., MILENKOVIC B., ZEREMSKI T., MILIC G., VUCKOVICH B. Persistent organic pollutants, heavy metals and radioactivity in the urban soil of Pristina City, Kosovo and Metohija. Chemosphere. 171, 415, 2017.

2. ZHU J., WANG Q., YU H., LI M., HE N. Heavy metal deposition through rainfall in Chinese natural terrestrial ecosystems: Evidences from national-scale network monitoring. Chemosphere. 164, 128, 2016.

3. TYLER G., OLSSON T. Concentration of 60 elements in the soil solution as related to the soil acidity. Eur. J. Soil. Sci. 52, 151, 2001.

4. TYLER G. Rare earth elements in soil and plant systems: A review. Plant Soil. 267, 191, 2004.

5. PERELOMOV L.V. Interaction of rare-earth elements with biotic and abiotic soil components. Agrochemistry 11, 85, 2007.

6. DUISSENBEKOV B., TOKMURATOV A., ZHANGABAY N., ORAZBAYEV Z., YERIMBETOV B., ALDIYAROV Z. Finite-difference equations of quasistatic motion of the shallow concrete shells in nonlinear setting. Curved Layer. Struct. 7 (1), 48, 2020.

7. MANCEAU A., MARCUS M.A., TAMURA N. Quantitative speciation of heavy metals in soils and sediments by synchrotron X-ray techniques. Rev. Mineral Geochem. 49 (1), 341, 2002.

8. KORCHAGINA K.V., SMAGIN A.V., RESHETINA T.V. Assessment of industrial pollution of urban soils based on the profile distribution of heavy metals and addition density. Soil Sci. 8, 988, 2014.

9. ABAKUMOV E.V. The theory of ecogenesis and soil ecology. In International scientific conference "The role of soils in the biosphere and human life": to the $100^{\text {th }}$ 
anniversary of the birth of Academician G.V. Dobrovolsky, to the International Year of Soils. Russia, 2015.

10. BORODIN K., ZHANGABAY N.Z. Mechanical characteristics, as well as physical-and-chemical properties of the slag-filled concretes, and investigation of the predictive power of the metaheuristic approach. Curved Layer. Struct. 6 (1), 236, 2019.

11. BERTINI I., GRAY G., STIFEL E., VALENTINE J. Biological inorganic chemistry: structure and reactivity. BINOM, Laboratory of Knowledge Moscow, 2013.

12. LIU X., CHEN J., WANG G.H., WANG W. H., SHEN Z.J., LUO M.R., GAO G.F., SIMON M., GHOTO K., ZHENG H. L. Hydrogen sulfide alleviates zinc toxicity by reducing zinc uptake and regulating genes expression of antioxidative enzymes and metallothioneins in roots of the cadmium/zinc hyperaccumulator Solanum nigrum L. Plant Soil. 400, 177, 2015

13. BARBOSA B.C.F., SILVA S.C., DEOLIVEIRA R.R., SILVA S.C., CHALFUN A. Jr. Zink supply impacts on the relative expression of a metallothionein-like gene in Coffea arabica plants. Plant Soil. 411 (1-2), 179, 2017.

14. CALDELAS C., WEISS D.J. Zinc Homeostasis and isotopic fractionation in plants: a review. Plant Soil. 411, 17, 2017.

15. SAVICHEV A. T. Rare heavy metals in soils of the humid climate according to x-ray fluorescence analysis: abstract of thesis doctor of agricultural sciences: 03.02.13. Dissertation. V.V. Dokuchaev Soil Science Institute, 2012.

16. VODYANITSKY YU. N. Natural and technogenic compounds of heavy metals in soils. Soil Sci. 4, 420, 2014.

17. DING Q., CHENG G., WANG Y., ZHUANG D. Effects of natural factors on the spatial distribution of heavy metals in soils surrounding mining regions. Sci. Total Environ. 578, 577, 2017.

18. TENG Y., WU J., LU S., WANG Y., JIAO X., SONG L. Soil and soil environmental quality monitoring in China: A review. Environ Intern. 69, 177, 2014.

19. TOTH G., HERMANN T., SZATMARI G., PASZTOR L. Maps of heavy metals in the soils of the European Union and proposed priority areas for detailed assessment. Sci. Total Environ. 565, 1054, 2016.

20. VODYANITSKY YU.N. Taking into account the geochemical features of the territory and weather conditions when normalizing heavy metals in soils. Agrochemistry. 2, 66, 2014.

21. KHAZIEV F. Kh., BAGAUTDINOV F. YA., SAKHABUTDINOVA A.Z. Ecotoxicants in the soils of Bashkortostan. Gilem, Ufa, 2000.

22. STAROVA N.V. Ecological problems: principles for their solution on the example of the South Urals. Science, Moscow, 2003.

23. ASYLBAEV I.G., KHABIROV I.K., RAFIKOV B.V., LUKMANOV N.A., GABBASOVA I.M. Geochemistry of thorium and uranium in soils of the Southern Urals. Eurasian Soil Sci. 50 (12), 1406, 2017.

24. ASYLBAEV I.G., GABBASOVA I.M., KHABIROV I.K., GARIPOV T., LUKMANOV N., RAFIKOV B.V., KISELEVA A., KHUZHAKHMETOVA G., MUKHAMEDYANOVA A., MUSTAFIN R.F. Bioaccumulation of chemical elements by old-aged pine trees in the southern Urals. J. Eng. Appl. Sci. 13 (11), 8746, 2018.

25. STATE COMMITTEE FOR ENVIRONMENTAL PROTECTION OF THE RUSSIAN FEDERATION. PND F 16.1: 2.3: 3.11-98. Quantitative chemical analysis of soils.
Methodology for measuring the content of metals in solid objects by inductively coupled plasma spectrometry, 2005 .

26. ASYLBAEV I. G., KHABIROV I. K. Features of the accumulation of rare-earth elements in soils and rocks of the Southern Urals. Agrochemistry. 7, 58, 2015.

27. ASYLBAEV I.G., KHABIROV I.K. The content of alkaline and alkaline earth metals in the soils of the South Urals. Soil Sci. 1, 1, 2016.

28. MOTUZOVA G.V., BEZUGLOVA O.S. Ecological monitoring of soils. Gaudeamus, Moscow, 2007.

29. VODYANITSKY YU. N., GREBENKIN N.A., MANAKHOV D.V., SASHCHENKO A.V., TYULENEVA V.M. Positive anomalies in the uranium content in peatlands of the humid zone. Soil Sci. 12, 1492, 2019.

30. KONOPKA A., PLYMALE A.E., CARVAJAL D.A., LIN X.J., MCKINLEY J.P. Environmental controls on the activity of aquifer microbial communities in the 300 area of the Hanford Site. Microb. Ecol. 66 (4), 889, 2013.

31. BELLI K.M., DICHRISTINA T.J., VAN CAPPELLEN P., TAILLEFERT M. Effects of aqueous uranyl speciation on the kinetics of microbial uranium reduction. Geochim. Cosmochim. Acta. 157, 109, 2015.

32. PROTASOVA N.A., SCHERBAKOV A.P. Trace elements in chernozems and gray forest soils of the Central Chernozem region. Publishing house of Voronezh, Voronezh, 2003.

33. ALVAREZ IGLESIAS P., RUBIO B. Trace metals in shallow marine sediments from the Ria de Vigo: source pollution, speciation and early diagenesis. In Geochemistry - Earth, System Processes edn (Ed. D. Panagiotaras). InTech Rijeka, 2012.

34. GUISTI L. Heavy metals in urban soils of Bristol (UK). Initial screening for contaminated land. J. Soils Sediments. 11, 1385, 2011.

35. RUBIO B., NOMBELA M.A., VILAS F. Geochemistry of major and trace elements in sediments of Ria de Vigo (NW Spain): an assessment of metal pollution. Mar. Pollut. Bull. 40, 968, 2000.

36. ENDOVITSKY A.P., KALINICHENKO V.P., MINKINA T.M. Consisting of lead and cadmium in chernozem after making phosphogypsum. Soil Sci. 3, 340, 2014.

37. ENDOVITSKY A.P., KALINICHENKO V.P., ILYIN V.B., IVANENKO A.A. Association coefficients and activity of cadmium and lead ions in soil solutions. Eurasian Soil Sci. 2, 218, 2009.

38. GABBASOVA I.M., SULEYMANOV R.R., KOMISSAROV M.A., GARIPOV T.T., SIDOROVA L.V., NAZYROVA F.I., KHABIROV I.K. Multiple assessment of the soil cover in the area of natural monuments Tratau and Yurak-tau monadnocks under conditions of technogenic loads. Eurasian Soil Sci. 47 (2), 35, 2014.

39. ZAURBEKOV N., AIDOSOV A., ZAURBEKOVA N., AIDOSOV G., ZAURBEKOVA G., ZAURBEKOV I. Emission spread from mass and energy exchange in the atmospheric surface layer: Two-dimensional simulation. Energ. Source. Part A. 40 (23), 2832, 2018.

40. CHIMITDORZHIEVA G.D., NIMBUEVA A.Z., BODEEVA E.A. Heavy metals (copper, lead, nickel, cadmium) in the organic part of the gray forest soils of Buryatia. Eurasian Soil Sci. 2, 166, 2012.

41. BOWEN H.J.M. Environmental chemistry of elements. Academic Press London, New York, 1979.

42. MINKINA T.M., NEVIDOMSKAYA D.G., POL'SHINA T.N., FEDOROV Yu. A., MANDZHIEVA S.S., CHAPLYGIN V.A., BAUER T.V., BURACHEVSKAYA M.V. Heavy metals in the soil-plant system of the Don 
River estuarine region and the Taganrog Bay coast. J. Soils Sediments. 17, 1474, 2017.

43. KASHULINA G.M. Aerotechnogenic soil transformation of the European subarctic region. Dissertation. Kola Science Center RAS, 2002.

44. SPITSOV D., NEKRASOVA L., KONDRATENKO L., PUSHKIN S., KLYUCHNIKOV D. The Effect of Agricultural Practices on the Drinking Water Quality: A Case Study. Asian J. Water, Environ. Pollut. 17 (2), 73, 2020.

45. MATVEEV A.V., BORDON V.E. Geochemistry of the Quaternary sediments of Belarus. Navuka, Minsk, 2013.
46. POZNYAK S.S. The content of heavy metals $\mathrm{Pb}, \mathrm{Ni}, \mathrm{Zn}$, $\mathrm{Cu}, \mathrm{Mn}, \mathrm{Zr}, \mathrm{Cr}, \mathrm{Co}$ and $\mathrm{Sn}$ in the soils of the Central zone of the Republic of Belarus. Scientif. J. NRU ITMO 1, 23, 2011.

47. RUBIO B., NOMBELA M.A., VILAS F. La contaminaciyn por metales pesados en las Rнаs Baixas gallegas: nuevos valores de fondo para la Rна de Vigo (NO de Espaca). J. Iberian Geol. 26, 121, 2000.

48. VODYANITSKY YU. N. Accounting for geochemical features of the territory and weather conditions during the normalization of heavy metals in soils. Agrochemistry 2, 66, 2014. 